\title{
Using Sociology and Anthropology to Explain the Perpetual Underdevelopment of Africa and the Caribbean
}

\author{
Valentine Smith \\ Cipriani College of Labour and Cooperative Studies, Trinidad and Tobago
}

\begin{abstract}
The epistemological and ontological variants of the Age of Enlightenment set in motion a new way of thinking among European people. Rationalization became the watch word among Europeans. Since rationalization is a deliberate, matter-of-fact calculation of the most efficient means to accomplish a particular goal, the enslavement of Africans and colonization of the Caribbean can therefore be interpreted as the most efficient means for the Europeans to accomplish the goals of mercantile and industrial capitalism. These goals are persistent today due to the permanent existence of the ethnocentric core-periphery dichotomy between the Western world and Third World countries. The objective of this study is to argue that the Age of Enlightenment by its very nature was part of the cultural metamorphosis which took place in Europe in the eighteenth century where it only benefitted Europeans' intellectual, scientific, and economic development. The methodology is based on a discursive methodological approach in which anthropology, sociology and historiography have been utilized. The finding of this research is exploratory, but it can be used to stimulate the minds of young African and Caribbean scholars so that they can build the relevant episteme that incorporate their worldview.
\end{abstract}

Keywords: sociology, anthropology, historiography, underdevelopment, age of enlightenment

\section{Introduction}

The object of social theory is to reveal the scientific truth about the human society. All social science theorizing is a reconstruction to explain the various facets of human existence. Theories of development explain both the equitable and inequitable relationships that exist between Europe and Third World countries. "By using for the first time in such context, the word 'underdevelopment,' President Truman of the United States of America, changed the meaning of development....a new perception of one's own self and of the Other was suddenly created. According to Esteva (1992) 'development' was transmogrified." Thus development came to be understood as the opposite of 'underdevelopment.' Underdevelopment carried the meaning of lacking the basic tools of science, technology, rationality, state, and market; all of which are the key metaphors of modernity. There is therefore a dire need for the development of an African and Caribbean epistemology.

Whether it was by chance or by fate, the cultural metamorphosis that took place in Europe was associated with a series of revolutions in thought and social organization, which began with the Renaissance, and proceeded through the Age of Exploration and Colonization, the Scientific
Revolution, the Age of Enlightenment, the emergence of capitalism and democratic state, culminating in the Industrial Revolution. According to European's epistemology and ontology, the Age of Enlightenment ushered in a new era of social behaviour focused on science, economics, secular religiosity, and material development. I am able to make this statement based on the fact that the Europeans experienced an uninterrupted cultural revolution. Africa and the Caribbean's inclusion were only part of the rationalization of Europe's economic development, a process that involved the cultural interruption of African peoples.

According to European's epistemology, economic development is linked to the objectivism of European's science. It was science and research which transformed Europe's traditional way of life, into modern Europe. Africa and the Caribbean did not experience the Age of Enlightenment. The Europeans were the ones who were able to turn their non-material culture into material culture. The production of raw material depended on mercantile capitalism and the technological advancement, of the Industrial Revolution. Europe's scientific enthusiasm immersed itself in the rationalization process of the Enlightenment project. Colonization, as an inevitable process of the Industrial Revolution created an ideal reciprocal relationship between Africa, the Caribbean 
and the Metropolis. It was a well worked out plan, which entailed the forced transportation of millions of human beings to work on the sugar plantations. In this paper I propose to use both sociology and anthropology to explain why Africa and the Caribbean have remained in perpetual underdeveloped.

The psychology of coercion must be understood as a contributing factor within the development discourse. There is evidence of "belonging to somewhere else" that still lingers in the minds of the descendents of these migrants. Visible examples are; in the forms of ethnic identities, syncretic religions, homage to Mother countries and the formation of diasporas. These are the characteristics of societies that are; hybridized, and underdeveloped. This paper will argue that Africa and the Caribbean by their very nature in the development discourse will remain underdeveloped.

The Enlightenment put in motion a series ontological and epistemological issues that focus on claims about what exists in the world and also about what exists is made known. It was an attempt to create a rational, progressive and cultivated European society based upon the empirically discovered and/or logically deduced laws of nature and human nature. Its dynamic form was a critique of accepted values and search for truth. Post-modernist thought will argue that the Enlightenment failed because it deliberately obscured the symbolic or discursive nexus of rationality and social actuality, thereby contributing to economic, cultural and technological domination by particular groups such as patricharchy, capitalists and scientific experts. To use the language of continental critical theory, the Enlightenment regressed into ideology and its cultural vision became so detached from lifeword as to offer no serious resistance to commodification. It was the Age of Enlightenment in the eighteenth century which finally laid the ground work for the conceptualization of differences.

\section{Perception of Difference}

According to Sachs (1990) the rise of humanity by no means obliterated the image of the Other in European thought. Just as Christians had their heathens, philosophers of the Enlightenment had their savages. Both figures embodied the negation of what the respective societies held as their self-images. European civilization contradicted the very idea of one mankind. The point I will like to make focuses around the production of discourse under conditions of unequal power. Foucault's (1980) notion of a 'discourse' is the idea that social facts can never be conceived of as being 'true' or 'false'. The very language we use to describe facts imposes truth or falsity upon those facts. Hence it is the discourse itself that creates the truth about a particular topic and competing discourses create competing truths. Truth lies not in the relationship between discourse and social reality but in the relationship between discourse and power. It is the relationship between discourse and power that decides which one of the many truths is accepted as the truth. According to Foucault (1980) power produces knowledge and power and knowledge directly imply one another because there is no power relation without the correlative constitution of a field of knowledge, nor any knowledge that does not presuppose and constitute power relations (Foucault 1980).

Power relations are what some anthropologists refer to as "the colonial move." This move entails constructions of the colonial/Third World subject in/through discourse in ways that allow the exercise of power over it. According to Bhaba (1990) colonial discourse although "the most theoretically underdeveloped form of discourse, is crucial to the binding of a range of differences and discriminations that inform the discursive and political practices of racial and cultural hierarchization." Knowledge contained within the discourse of Orientalism played a key part in allowing Europe to subjugate the nonWestern world. It also provided the necessary knowledge for the actual colonial conquest (Young 1990). It also created not only knowledge but the reality they appear to describe (Said 1985). According to Goldberg (1993) "naming the racial Other, for all intents and purposes, is the Other. In the case of the Oriental, no Other behind or beyond the invention of the Other in the Other's name. These practices of naming and knowledge construction deny all autonomy to those so named and imagined, extending power, control, authority and domination over them (Said 1985). To extend Said's analysis of the 'Oriental' to the case of race in general, social science of the Other establishes the limits of knowledge about the Other, for the Other is just what the racialized social science knows (Goldberg 1993).

There is yet another problem that arises from Said's argument which can contribute to the argument of this paper. For Said (1985), the real issue is whether there can be a true representation of anything, or whether any or all representations, are embedded first in the language and then in the culture, institutions, and political ambience of the representer. Said 1985) further argued that a representation is eo ipso implicated, intertwined, embedded, interwoven with a great many other things beside "truth", which is itself a representation. Finally, representation cannot be 'truthful' and 'truth' 
is but a representation, constituted 'by some common history, tradition, universe of discourse' (Said 1985).

\section{The Relevance of Race}

It is important to note at this point, the relevance of race as a factor in the Enlightenment project. The Enlightenment project is all about "Whiteness" so that any other colour will be perceived as inferior and being inferior, strategically your colour will place you in the ascribed position of colonialism. European colonization is a bureaucratic organization which has been organized to be rational and sustainable. The evidence of its existence is all around us. We in the Caribbean are experiencing the modern phase of this imperialism in the form of neo-colonialism. In order for the reader to appreciate objectification and its reciprocal relationship with commodification, it is important for me to reiterate again and again, by saying that Europe's colonization strategies have remained stored as schemas in the minds of European people. Europeans see themselves as super-ordinate and the "Other" as sub-ordinate.

Sweet (2003) argued that the policies and ideas that flowed from understandings of the African as inferior served to crystallize racial hierarchies across Europe. The first transnational, institutional endorsement of African slavery occurred in 1452 when the Pope granted King Alphonso V of Portugal the right to reduce all the non-Christians in West Africa to perpetual slavery (Saunders 1982; as cited in Sweet 2003). According to Sweet (2003), by the second half of the $15^{\text {th }}$ century, the term "Negro" had become essentially synonymous with "slave" across the Iberian Peninsula and had literally come to represent a race of people, most often associated with black Africans and considered to be inferior. Racebased ideas of European superiority and religious beliefs in the need to Christianize "heathen" peoples contributed to a culture in which enslavement of African could be rationalized and justified. Therefore, Europeans participation in African enslavement can only be partially explained by the needs for labour, profit and religious motives. According Sweet (2003) the Trans-Atlantic slave trade placed Africans in a new and different category of enslaveable peoples in terms that flow from an understanding of the African as inferior beings.

\section{Understanding Colonialism}

According to Osterhammel (1996), colonialism is not just any relationship between master and servants, but one in which an entire society is robbed of its historical lines of development, externally manipulated and transformed according to the needs and interests of the colonial rulers. Asad (1991) further explained colonialism as imperial dominance not as a temporary repression of subject populations but as an irrevocable process of transmutation, in which old desires and ways of life were destroyed and new ones took their place. The Caribbean experience of colonialism, witnessed the genocide of the indigenous people and the importation of millions of "foreigners." In the Caribbean it was all about plantation economy, a process which required vast amount of manpower to explore, clear land, build colonies, mine precious metal, and provide the settlers with subsistence. The Europeans first tried to meet these needs by enslaving the indigenous people, and relying on European indentured labour. When both of these sources proved inadequate to meet the needs for labour, Europe turned to Africa (Wolf 1982). Williams (1994) argued that Caribbean colonization was the greatest migration the world did ever witness.

The transported Negro, on the other hand, in a strange environment, handicapped by his ignorance of the white man's language was pre-eminently fitted for exploitation (Williams 1994). Williams understood the Enlightenment project and its derivative the Industrial Revolution, so he was quite aware that European's modernity only link with Africa was its inexhaustible supply of labour. The development of plantation economies depended on the production of sugar, tobacco, and cocoa, all of which were contingent upon workers with particular attributes of material cultural knowledge, agricultural skills and the physical capability to acclimatize to the new environment. Thus was the Negro introduced into his new habitat, and drawn into the orbit of Western civilization (Williams 1994). The sugar produced by Afro-Caribbean slaves sweetened the coffee and tea that were important dietary supplements of Europe's burgeoning proletariat during the nineteenth century (Mintz 1985).

Yet, the impact of colonialism was not a one way traffic, but a dialectical interplay, in which, however great the West's political and military superiority, pre-colonial forms of social organization and culture persisted, though often combined with new Western elements (Worsley 1992). Thus new syncretic religions emerged, adapted to the new conditions of colonial life and to the interests of the colonized. Christianity was not the only ideology borrowed from the Western world. The modern secular ideologies of the West such as liberalism, nationalism, socialism and Marxism were the ideologies that were seized upon by the new nationalist movements which were to finally bring the epoch of direct imperialism to an end by the 1960s (Worsley 1992). 


\section{The Making of Africa and the Caribbean}

It is important to note that the only countries in the world that are not developed to Western standards are the African countries, the Anglophone Caribbean countries and the Latin American countries. Anthropologist, Charles Wagley (1960) suggested that America was best approach via the idea of three "cultural spheres:" Euro-America, Indo-America, and Plantation-America. He identified the factors which brought about the formation of these three culture spheres as: "the nature of the physical environment, the density of the aboriginal population, the level of complexity of the native societies and culture, the sources of post-Columbian immigration, the form of European occupation since 1500AD and the processs of historical events as they unfolded in the New World" (Wagley 1960). Very noticeable in this spherical argument, is the fact that Europeans, who came to the New World, permanently inhabited the temperate geographical regions. They came excited, happy and willingly with the intention of making a better life based on the philosophy of Max Weber's (1976) "the Protestant Ethics and the Spirit of Capitalism." They came from all parts of Europe. Today these countries are Canada, United States of America, Argentina and southern parts of Brazil. All these countries have a large white population and they are industrialized countries.

By contrast, Plantation America comprises of the Caribbean countries, southern part of the United States and Brazil (mostly the northern regions). African migration to Plantation America was an integral part of colonialism. It was based on coercion, and trickery. The Northern Europeans were able to use their rationalization skills to achieve their capitalist goal. The triangular trade would be crucial in the development of British industry, which will in turn lead to the Industrial revolution. this industrial revolution was financed through the "accumulation of capital from slaves, the key component of the labour intensive plantations (Williams 1994). The commercial capitalism of the eighteenth century was built upon slavery and monopoly, while the Industrial capitalism of the nineteenth century destroyed slavery and monopoly (Williams 1994). The Southern parts of the United States of America, by their geographical location are tropical in nature. These southern states experienced plantation economy and plantation slavery. Slavery throughout Plantation America was inhumane, brutish and at times sadistic. There is evidence to this day of racial discrimination in its bigoted form, still existing in these southern states of the United States of America. The Civil Rights movement, ameliorated, but did not completely free African Americans. African
Americans are still considered the poorest and most stereotyped group existing in the United States of America.

These countries are still on the periphery and the Western countries have remained as the core. . According to Frank (1969), modernization created a one way economic flow. The funnelling back of wealth created in underdeveloped countries to the developed world, not only in the form of capital, but of human capital: the vast exodus of millions to the labour -markets of the 'centre,' including the "brain drain" of people whose education had been funded by their home countries but who now worked for benefit of the advanced countries where they lived.

Africa and the Caribbean are not involved in any significant scientific research especially in the areas of the natural sciences and if they do, their human capital has the tendency to migrate to the core due to the economic push and pull ideology of "dependency migration." Africa, also known as the stereotypical Black continent, can be considered the continent with an abundance of mineral wealth and vast variation in flora and fauna. Africa had been incorporated into the Europeans' colonial project as part of its development plan. The exploitation of the continent began as early as the sixteenth century and has transformed itself today as neo-colonialism. Almost, every Northern European country had laid claim to a portion of Africa. Was it because they loved the people of Africa? The capitalist economic trajectory designed by these Europeans, perceived Africans as insignificant, ignorant, and lacking of knowledge when it come to searching for the truth European style. Africa has become a "periphery/core culture, continuously dominated by formal (I.M.F. and World Bank) informal (supply of arms and ammunition to maintain political instability) neo-colonial strategies.

Inherent in this argument, is the problem of culture. African unification is based on cultural differences. These differences are the bases for the divide and rule strategy that is continuously propagated among and between African countries by the Western World. Since unity is strength, it is important for the division to be maintained. This is where African anthropology can play a significant role in the decolonization of Africa. According to Mudimbe (1988) Africa has been re-invented in different stages. The first stage saw North Africa as part of the classical Mediterranean world; the second concerned Africa's interaction with Semitic peoples; the third was stimulated by the birth of Islam and its expansion both north and south of the Sahara; the fourth came with the impact of European capitalist penetration and subsequent colonization; and finally, globalization. In order to contain the forces of "Otherization," there is need for the process of 
refounding and reassuming an interrupted historicity within representations. African can have greater autonomy over how they are represented and how they can control their own social and cultural models in ways not so mediated by a Western episteme and historicity (Mudimbe 1988).

\section{Economic Development}

The Independent movement in the Caribbean and Africa was part of a broader economic "off-loading" by European countries that were devastated in the war. The United States of America met with Europeans countries including the UK at Bretton Wood, to discuss their economic recovery process. This is where the I.M.F and the World Bank were developed to propagate economic development to the countries that were devastated. England had to face and feed her Commonwealth nations but she was devastated. It is therefore understandable, that when the enthusiastic European trained Third World nationals who were experiencing nationalism, felt that independence will set free Third World countries from the arms of colonialism. I will like to argue that they did not take into consideration that the structures of colonialism were permanently constructed within the fabrics of Western development ideology.

By this I mean, the paradigm had shifted to the United States of America where she is now in control of economic development on a global scene. Independence from the Industrial countries of Europe and modernization from the United States of America can be considered a recipe for disaster from the beginning. It has done nothing economically substantial for these countries. We speak about the service industry as a form of economic development but is it capable of being sustained? My view on the service industry is that it is basically another form of slavery. In this I mean that Caribbean people are now serving the descendants of the former European colonizers for a fee. How much scientific research does the service industry need? An undertaking like this routinely requires unskilled labour. According to Erikson and Lawrence (2008), the Caribbean already has a small manufacturing sector, but this is unlikely to be an area of future growth. They went to show that the exporting of natural resources has been another common strategy of development, but is another area where the Caribbean is at a disadvantage. It is no longer competitive in its traditional agricultural exports of bananas and sugar. Trinidad and Tobago is the only country that possesses significant oil and natural gas reserves. With rising oil prices, Trinidad and Tobago has experience an economic boom, but the profits primarily benefit a concentrated group (Erikson and Lawrence 2008).

In his inaugural address as president of the United States on January 20, 1949, Harry Truman announced his concept of "fair deal" for the entire world. Hence modernization theorists found Max Weber's(1976) classic analysis of the connection between the emergence of historic capitalism in the West and the emergence of Protestantism highly relevant for contemporary development strategies in the Third World. For Weber, it was not that the Protestant religion caused the growth of capitalism; nor was it the converse, that Protestantism was simply a 'reflection' of capitalism. It was the ethic of Protestantism, the code of conduct built into it. It was an ethic which prescribed the virtues of dedication to one's calling, the ascetic husbanding of wealth rather than its consumption, and the application of rational thought and organization so as to achieve one's ends with minimum cost.

One can clearly see that this project was entirely an American undertaking. Third World countries did not have any say in the planning or the implementation. From Truman's point of view Third World countries were the "Other", and the "Other" must be taught by the United States of America on how to modernize. The most influential critique of modernization theory came from Andre Gunder Frank (1969). According to Rodney (1972), the 'periphery' was not simply 'underdeveloped,' but had been underdeveloped by other countries which constituted the 'centre' of this world-system. Looking for the causes of underdevelopment within any particular country or in the underdeveloped countries as a whole was therefore methodologically wrong, for the cause was to be found in the centre, not the periphery (Frank 1969). According to Weber (1961) modern European society encourages rationality, deliberate, matter of fact calculations of the most efficient means to accomplish a particular goal. Sentiment has no place in a rational world view, which treats tradition simply as one kind of information. It is therefore in this context, that one can understand the rationale of the Europeans. Colonialism laid down the ground work for underdevelopment and modernization theory completed the cycle. It is therefore no wonder why Africa and the Caribbean have remained underdeveloped.

The cultural persistence of Whiteness is demonstrated in the shift from mercantile colonialism to electronic colonialism. Electronic colonialism according to McPhail (1981) is the dependency relationship established by the importation of communication hardware, foreign-produced software, along with professionals and related information protocols, that vicariously establish a set of foreign 
norms, values, and expectations which in varying degrees, may alter the domestic cultures and socialization processes. According to David and Crawley (2001) free trade and the free flow of information became the dominant philosophies of the late twentieth century, with the United States as the chief protagonist of both. Mowlana (1993) argued that the world is divided into dominant central or dependent peripheral countries, with a predominant news flow from the former to the latter. The Centre countries are rich in technology as well as communication. This technological advancement has deepened the division of the world into 'haves' and 'have nots' and the former influenced upon every aspect of the latter (Mowlana 1993).

\section{Conclusion}

Caribbean countries cannot resist underdevelopment. Their small island size and therefore their small, undiversified economies augment a historically inherited economic dependency (Demas 1965; Worrel 1987). Nothing much has changed since this statement. The combination of small size, and external dependence, further, work together to thwart local economic development in the Caribbean (Richardson 1993). In essence, Caribbean countries have an interrelationship between small island size and inevitable mono-cultural economies. Yes, sunny for tourism but similarly every place on these islands suffers in the event of a hurricane or prolonged drought.

According to Mintz (1974), external economic dependency in the region affects even the small amounts of local currency that Caribbean people carry in their pockets. A money economy has existed in the region since slavery (Mintz 1974). Caribbean money is ultimately tied to international financial markets. So that local currency devaluation or inflation, which may have much more to do with financial decisions elsewhere than with local conditions, often has the insidious effect of causing Caribbean people to work harder in order to purchase the same imported item they bought last month for less (Nietschmann 1979).

The relationship of exploitation has been a common feature of the European intervention in Africa. It started with the arrival of the missionaries, and continued with the arrival of European merchants and mercenaries, and most lately, with the western multinational corporations, including the Chinese. When economists look at African countries they generally find their economies are weak. Some of these economic signs are; a weak Gross Domestic Product (GDP), the export of primary products and agricultural products are getting smaller, a low level of using modern technology and a terrible national debt to richer countries and the gap between rich and poor getting wider and wider.

Throughout recorded history, and including the present, the economic benefits from the Caribbean environments, whether commodity or scenery, have therefore accrued "not to inhabitants but to outsiders" ( Lowenthal 1987). The Western world has been able to continuously manipulate the power relationships of the world. The African has lost his native cultural originality and embraced the culture of the Mother country (Fanon 1952; reprinted 2008). As a result of the inferiority complex engendered in the mind of the Black Subject, he will try to appropriate and imitate the cultural code of the colonizer (Fanon 1952; reprinted 2008).Certainly this false consciousness generated, has been able to substantiate my argument that African countries and the Caribbean had been blue-printed to be underdeveloped, a process we must rationalize as inevitable when it comes to Europe's development agenda.

\section{References}

Asad, T. (1991). From the history of colonial anthropology to the anthropology of western hegemony. Colonial situations: Essays on the Contextualization of Ethnographic Knowledge. ED. George Stocking Madison, WI: University of Wisconsin Press, 34, 314-324.

David, P \& Crawley, W. (2001). Satellites over South Asia, broadcasting culture and public interest. New Delhi: Sage Publications.

Demas, W. G. (1965). The economics of development in small countries with special reference to the Caribbean: Montreal: McGill University Press.

Erikson, D \& Lawrence, J. (2008). Beyond tourism: The future of the service industry in the Caribbean. Caribbean Paper No. 3.

Esteva, G. (1992). Development; Sachs (eds.) The development dictionary: A guide to knowledge as power: London; Zed Books.

Fanon, F. (2008). Black Skin, White Masks. Pluto Press.

Foucault, M. (1980). Power/Knowledge, Harvester.

Frank, A. G. (1969). The sociology of development and the underdevelopment of sociology, in Latin America: Underdevelopment or Revolution? Monthly Review Press.

Goldberg, D. (1993). Racist culture: Philosophy and politics of meaning. Blackwell Publication.

Lowenthal, A. F. (1987). Forward. In land and development in the Caribbean, ed. J. Besson \& J. Momsen. London: Macmillan.

McPhail, T. (1981). Electronic colonialism: The future of international broadcasting and communication. Newbury Park: Sage.

Mintz, S. W. (1974). Caribbean transformations. Chicago: Aldine.

Mintz, S.W. (1985). Sweetness and power: The place of sugar in modern history. New York: Viking.

Mowlana, H. (1997). The new global order and cultural ecology, Media, Culture and Society, 15(1), 9-27.

Mudimbe, V. Y. (1988). The invention of Africa: Gnosis, philosophy and the order of knowledge, Bloomington; Indiana University Press.

Nietschmann, B. (1979). Ecological change, inflation, and migration in the far Western Caribbean. The Geographical Review, 69, 1-24. 
Osterhammel, J. (1997). Colonialism: A theoretical overview. Princeton, N.J.: Markus Wiener Publishers.

Richardson, B. C. (1993). The Caribbean in the wider-world, 14921992: A Regional Geography. Cambridge University Press.

Rodney, W. (1972). How Europe Underdeveloped Africa, Tanzania Publishing House.

Sachs, W. (1990). The archaeology of the development ideas' Interculture, 23 (4).

Said, E. (1985). Orientalism, Penguin.

Saunders, K.(1982). Workers in bondage: The origins and bases of unfree labour in Quensland, St Lucia: University of Queensland Press.

Sweet, J. H. (2003). Spanish and Portuguese influences on racial slavery in British North America, 1492-1619. Paper presented at Collective Degradation: Slavery and the Construction of Race, Proceeding of the Fifth Annual Gilder Lehrman Center International Conference, Yale University, New Haven Connecticut.
Wagley, C. (1960). Plantation-America: A culture sphere. In Caribbean studies: A symposium, edited by Vera Rubin. Seattle: University of Washington Press.

Weber, M. (1968). Economy and society: An outline of interpretive sociology, Vol. 3. G. Roth \& C. Wittich (eds.). New York: Bedminster Press.

Weber, M. (1976). The Protestant Ethics and the Spirit of Capitalism, Scribner; Allen \& Unwin edition.

Williams, E. (1994). Capitalism and Slavery. Chapel Hill: University of North Carolina Press, Rev. Ed.

Worsley, P. (1992). The New Introducing Sociology, Penguin.

Wolf, E. (1982). Europe and the people without history. Berkeley: University of California Press.

Worrel, D. (1987). Small island economies: Structure and performance in the English-speaking Caribbean since 1970. New York: Praeger.

Young, R. (1990). White mythologies: Writing history and the West, London: Routledge. 